\title{
CONTROL OF Neospora caninum IN SEMEN OF BULL
}

(Controle do Neospora caninum no sêmen de touros)

\begin{abstract}
Ana Claudia Machinski Rangel de Abreu ${ }^{1}$ https://orcid.org/0000-0002-8025-905X, Romildo Romualdo Weiss ${ }^{1}$ https://orcid.org/0000-0002-7218-1184, Eduarda Maciel Busato ${ }^{1}$ https://orcid.org/0000-0001-6099-7680, Rosangela Locatelli Dittrich ${ }^{\mathbf{1}}$ https://orcid.org/0000-0001-5144-6422, Luiz Ernandes Kozicki² https://orcid.org/0000-0002-3700-1811, Natalia Santana Siqueira de Lara $^{1}$ https://orcid.org/0000-0001-8977-9740, Glaucia Aparecida Aschenbrenner ${ }^{1}$ https://orcid.org/0000-0001-7575-9669
\end{abstract}

Universidade Federal do Paraná. Curitiba, Paraná, Brasil; Pontifícia Universidade Católica do Paraná, Curitiba, Paraná, Brasil.

*Corresponding author: natyslara@gmail.com

ABSTRACT: The objective of the present study was to develop a diluent of bull semen efficient in the control of Neospora caninum. The antimicrobial test (experiment 1) trimethoprim isolated (TRI) and associated with sulfadiazine (SDT) and sulfamethoxazole (SMT), clarithromycin (CLA), erythromycin (ERI), azithromycin (AZI) and clindamycin (CLI) was performed using cell culture and evaluated for the presence of free tachyzoites and the cytopathic effect in the monolayer. The antimicrobials that proved effective in controlling the tachyzoites in vitro were used in the preparation of the diluent for the semen. Each antimicrobial was evaluated for sperm toxicity (experiment 2) with 8 groups (7 groups received an antibiotic in the diluent except for 1 group - control group). In relation to the morphological analysis, the SMT and AZI groups showed more acrosomal and tail defects. The SDT, SMT and AZI groups presented lower values of Average Path Velocity. The Straight-line Velocity was lower in the SMT and AZI groups and the Beat/cross Frequency was also lower in the CLI and AZI groups. The Curvilinear Velocity values of the SDT, SMT and CLA groups were lower. The SMT, ERI and AZI groups showed lower values of Total Motility and Progressive Motility. As for flow cytometry, the SDT, SMT and AZI groups presented higher percentages of acrosome reaction and damaged plasma membrane. The antibiotics can be added to the diluent of bull semen were clindamycin, clarithromycin and trimethoprim.

Keywords: antibiotic; bovine; diluent; neosporosis; sperm.

RESUMO: O objetivo do presente estudo foi desenvolver um diluente de sêmen de touros eficiente no controle de Neospora caninum. O teste dos antimicrobianos (experimento 1) - trimetoprim isolado (TRI) e associado a sulfadiazina (SDT) e ao sulfametoxazol (SMT), claritromicina $(C L A)$, eritromicina (ERI), azitromicina (AZI) e 
clindamicina (CLI) - foi realizado utilizando cultivo celular e avaliado quanto à presença de taquizoítas livres e ao efeito citopático na monocamada. Os antimicrobianos que se mostraram eficazes no controle dos taquizoítos in vitro foram utilizados na preparação do diluente para o sêmen. Cada antimicrobiano foi avaliado quanto à toxicidade dos espermatozóides (experimento 2) sendo 8 grupos $(7$ grupos receberam antibiótico no diluente, exceto 1 grupo- grupo controle). Em relação à análise morfológica, os grupos SMT e AZI apresentaram mais defeitos de acrossoma e de cauda.Os grupos SDT, SMT e AZI apresentaram valores mais baixos da Velocidade de Trajeto. A Velocidade Progressiva foi menor nos grupos SMT e AZI e a Frequência de Batimentos de cauda também foi menor nos grupos CLI e AZI. Os valores de Velocidade Curvilinear dos grupos SDT, SMT e CLA foram menores. Os grupos SMT, ERI e AZI apresentaram valores mais baixos de Motilidade Total e Motilidade Progressiva. Quanto à citometria de fluxo, os grupos SDT, SMT e AZI apresentaram percentagens maiores de reação acrossomal e membrana plasmática lesada. Os antibióticos que podem ser adicionados ao diluente de sêmen bovino foram clindamicina, claritromicina e trimetoprim.

Palavras-chave: antibióticos; bovinos; diluente; neosporose; sêmen.

\section{INTRODUCTION}

Knowing the transmission pathways and life cycle of Neospora caninum is essential for the implementation of disease control measures, that include slaughter and replacement of seropositive animals, management techniques, among others (Reichel \& Ellis, 2006; Dubey et al., 2007). In N. caninum infected herds, control programs are based on the prevention of vertical transmission, elimination of seropositive animals, and the reduction of horizontal transmission, mainly by controlling the access of definitive hosts considered as sources of contamination, since they eliminate oocysts in the feces (Dubey et al., 2007) on pasture areas. Management measures such as removal of potentially infected tissues from the environment, e.g., aborted fetuses and placenta, which may serve as a source of infection for susceptible hosts, are recommended (Anderson et al., 2000).

The reproductive health of males is a decisive factor for artificial insemination programs. As the DNA of $N$. caninum was detected in semen of bulls (Ortega-Mora et al., 2003; Caetano-da-Silva et al., 2004; Ferre et al., 2005; Serrano-Martinez et al., 2007a; Doosti et al., 2015), studies evaluated venereal transmission of $N$. caninum in cattle, classifying it as a horizontal transmission route (Serrano et al., 2006; Serrano-Martinez et al., 2007b). Considering that neosporosis is an important cause of reproductive problems and causes significant economic losses in the agricultural sector, precautionary measures 
are necessary for the use of semen from bulls infected with $N$. caninum. The objective of this study was to develop an efficient bull's semen diluent to control of $N$. caninum in the semen.

\section{MATERIAL AND METHODS}

Experiment 1: In vitro test of the effective active principles and compounds against $N$. caninum

Tachyzoites of the $N$. caninum strain NC-1 were inoculated on VERO cells (African Green Monkey kidney cells) in $25 \mathrm{~cm}^{2}$ Roux flasks and kept in an oven at $37^{\circ} \mathrm{C}$ with $5 \%$ $\mathrm{CO}_{2}$. From two to three times a week, the cell culture monolayer was evaluated using inverted microscope to verify the cytopathic effect, caused by the multiplication of the tachyzoites. The F-10 HAM growth medium (Sigma-Aldrich) with $\mathrm{pH}$ adjusted to 7.4 and supplemented with $10 \%$ fetal bovine serum, $100 \mathrm{UI} / \mathrm{mL}$ potassium penicillin $\mathrm{G}, 50 \mu \mathrm{g} / \mathrm{mL}$ streptomycin sulfate, and $1.25 \mu \mathrm{g} / \mathrm{mL}$ amphotericin B was used for the exchange of cell culture medium.

The cell culture on culture flasks was scraped and the contents were transferred to sterile Falcon tubes for tachyzoites recovery. The suspension containing tachyzoites, cells and medium was centrifuged at 3000 RPM for 5 minutes, and the supernatant was removed.

The number of recovered tachyzoites was determined by Neubauer ${ }^{\circledR}$ chamber counting. After counting, each culture flask with established VERO cell monolayer was inoculated with $10^{4}$ tachyzoites totaling 8 cell culture flasks. Of these, 7 flasks received their respective antimicrobial which was added to F-10 HAM maintenance medium on the exchange days.

The antimicrobial agents tested were two sulfonamides (Sulfamadiazine, SigmaAudrich, and Sulfamethoxazole, Sigma-Audrich); an inhibitor of dihydrofolate reductase/thymidylate synthase (Trimethoprim - Trimethoprim $\AA$ ); three macrolides (Clarithromycin, Sigma-Audrich; Erythromycin - Erythromycin Inpharma ${ }^{\circledR}$; Azithromycin, Sigma-Audrich); and onelincosamide (Clindamycin, Sigma-Audrich). Trimethoprim was tested alone and in combination with Sulfonamides. In the flask considered as control group, no antimicrobials were added. The concentrations of the before mentioned active principles were established by Lindsay et al. (1994) and Lindsay et al. (1996) in cell culture. 
After inoculation of the $N$. caninum tachyzoites, the flasks were evaluated daily for 7 days using inverted microscope to verify the presence of tachyzoites and the cytopathic effect in the VERO cells monolayer.

Experiment 2: Evaluation of sperm after dilution in diluent containing efficient antimicrobials against $N$. caninum.

A 96-month-old Nelore bull (Bostaurus indicus) weighing $900 \mathrm{~kg}$ and received a diet based on corn silage and ryegrass hay with water and mineral salt ad libitum. The animal was previously evaluated for normal andrological parameters (CBRA, 1998). The ejaculate was collected using an estrus female and an artificial vagina.

With the results obtained in the experiment 1 , the antimicrobials that proved efficient in the control of tachyzoites in vitro were used in the preparation of the diluent for the semen. After the collection and evaluation of the semen, the sample was divided into eight experimental groups (same collection), then the diluent Tris-glycerol containing the antimicrobial of each group was added to seven of them, according to Table 1 . No antimicrobial was added to the control group. After the semen dilution, the groups were re-evaluated and then placed in $0.25 \mathrm{~mL}$ straw with a concentration of 30 million viable spermatozoa each, duly identified and sealed with polyvinyl alcohol. After being filled and closed, the straws were cryopreserved.

Table 1 - Experimental groups of antimicrobials with their respective active principles used in the preparation of the diluent for cryopreservation of bull semen.

\begin{tabular}{ccc}
\hline $\begin{array}{c}\text { Antimicrobial } \\
\text { groups }\end{array}$ & Active principles & Final concentration \\
\hline Control & - & - \\
SDT & Sulfadiazine and Trimethoprim & $10.0 \mu \mathrm{g} / \mathrm{mL}+1.0 \mu \mathrm{g} / \mathrm{mL}$ \\
SMT & Sulfamethoxazole and & $10.0 \mu \mathrm{g} / \mathrm{mL}+1.0 \mu \mathrm{g} / \mathrm{mL}$ \\
& Trimethoprim & $0.01 \mu \mathrm{g} / \mathrm{mL}$ \\
CLI & Clindamycin & $0.10 \mu \mathrm{g} / \mathrm{mL}$ \\
ERI & Erythromycin & $0.10 \mu \mathrm{g} / \mathrm{mL}$ \\
CLA & Clarithromycin & $10.0 \mu \mathrm{g} / \mathrm{mL}$ \\
TRI & Trimethoprim & $1.0 \mu \mathrm{g} / \mathrm{mL}$ \\
AZI & Azithromycin & $\mathrm{cL}$
\end{tabular}

SDT: Sulfadiazine and Trimethoprim; SMT: Sulfamethoxazole and Trimethoprim; CLI: Clindamycin; ERI: Erythromycin; CLA: Clarithromycin; TRI: Trimethoprim and AZI: Azithromycin.

\section{Post-thaw Evaluation of Semen}

Each experimental group was evaluated in triplicate, and the flasks were submitted to analysis after thawing in a water bath at $37^{\circ} \mathrm{C}$ for $30 \mathrm{~s}(\mathrm{CBRA}, 1998)$. The post-thaw 
evaluations were the following: sperm morphology in saline formaldehyde, sperm kinetics by computerized analysis and occurrence of acrosome reaction and plasma membrane damage of sperm cells by flow cytometry.

A $20 \mu \mathrm{L}$ aliquot of semen was diluted in $2 \mathrm{~mL}$ of saline formalin buffer solution to evaluate the morphological characteristics of spermatozoa. Morphologic analysis was performed by a differential count using 200 cells per sample under differential interference-contrast microscopy. The abnormalities were grouped and classified as acrosomal and tail defects.

The Computer Assisted Sperm Analysis (Hamilton Thorne Motility Analyzer, IVOS 12) was used for the computerized analysis of sperm kinetics. After thawing of the flasks, semen from each of the experimental groups was placed in the Makler chamber heated at $38^{\circ} \mathrm{C}$ for analysis of the sperm variables. The analyses were performed in setup adjusted for bovine seminal characteristics (cell size 5 pixels, cell intensity 55, average path velocity $75 \mu / \mathrm{s}$, straightness $80 \%$, average path velocity cut off $21.9 \mu / \mathrm{s}$, straight-line velocity cut off $6.0 \mu / \mathrm{s}$, minimum static intensity gates 0.25 and maximum 1.5 , minimum static size gates 0.6 and maximum 8.0, minimum elongation gates 0 and maximum 95, magnification 1.95, video source frequency $60 \mathrm{~Hz}, 2400$ light intensity, low photometer 73 and high photometer 125) and three fields were randomly evaluated for each sample. The sperm variables evaluated were: Total Motility - TM (\%), Progressive Motility - PM (\%), Average Path Velocity VAP $(\mu \mathrm{m} / \mathrm{s})$, Straight-line Velocity - VSL $(\mu \mathrm{m} / \mathrm{s})$, Curvilinear Velocity - VCL $(\mu \mathrm{m} / \mathrm{s})$, Lateral Head displacement - ALH $(\mu \mathrm{m})$, Beat/cross Frequency - BCF $(\mathrm{Hz})$, Straightness - STR (\%) and Linearity - LIN (\%).

The sperm evaluation by flow cytometry was performed using the BD LSR Fortessa (Becton Dickinson, Mountain View, CA, EUA) equipped with excitation lasers: 488-nm blue, $100 \mathrm{~mW}$ with 530/30nm and 695/40nm emission filters; 640-nm red, $40 \mathrm{~mW}$ with 660/20nm filter; and 405-nm violet, $100 \mathrm{~mW}$, with 450/50 nm filter. The probes were used for the evaluation of plasma and acrosomal membranes integrity of sperm cells by flow cytometry: Hoechst 33342 (H342); Propidium lodide (PI); Fluorescein Isothiocyanateconjugated Pisum sativum Agglutinin (FITC-PSA) and Mitostatus Red (Camargo et al., 2016). $1.5 \mu \mathrm{MPl} ; 7.0 \mu \mathrm{M} \mathrm{H342;}$ 1.0ng of FITC-PSA and 20nM of Mitostatus Red were added to each $200 \mu \mathrm{L}$ of semen from each group diluted in TALP-PVA (final concentration of $5 \times 10^{6}$ spermatozoa $/ \mathrm{mL}$ ). These samples were homogenized and incubated for 20 minutes in a water bath at $37^{\circ} \mathrm{C}$ and then subjected to flow cytometry. The data were evaluated using the BD FACSDiva ${ }^{\mathrm{TM}}$ software $\vee 6.1$ and four different categories were 
obtained: intact plasma and acrosomal membranes (CAT 1); intact plasma membrane and damaged acrosomal membrane (CAT 2); damaged plasma membrane and intact acrosomal membrane (CAT 3); and damaged plasma and acrosomal membranes (CAT 4) (Celeghini et al., 2008). In order to evaluate of spermatozoa with acrosome reaction, CAT 2 and CAT 4 were added together and to evaluate of plasma membrane damage, CAT 1 and CAT 2 were added together.

The results obtained in the experiment were submitted to the Shapiro-Wilk normality test. The variables presented an abnormal distribution, thus the repeated measures RM ANOVA on Ranks was carried out followed by the Dunnett test for comparison of the experimental groups with the control group. The statistical program used was Sigma Plot ${ }^{\mathrm{TM}} 12.0$ (Systat software, San Jose, CA), with significance level of 5\%.

\section{RESULTS AND DISCUSSION}

All antimicrobials tested (clarithromycin, erythromycin, azithromycin, clindamycin, and trimethoprim alone and associated with sulfadiazine and sulfamethoxazole) were effective in controlling the tachyzoites inoculated in the cell culture flasks. Intracellular tachyzoite groups, cell culture rupture and free tachyzoites were observed only in the control group along the inoculation week. These active principles were also tested by Lindsay et al. (1994) who also observed efficacy against $N$. caninum. Subsequently, Lindsay et al. (1996) tested the synergism between sulfonamides and DHFR/TS (dihydrofolate reductase/thymidylate synthetase inhibitor). In the present study, the results obtained corroborate the efficiency of the concentrations previously tested.

A crucial point is that the active principles used in semen diluents should not present toxicity to sperm cells. The adverse effect has been associated with some antibiotics (BACK et al., 1975), as they may affect the functionality and integrity of the spermatozoa plasma membrane. To date, there have been no studies testing the interaction of clindamycin, clarithromycin, azithromycin, trimethoprim alone and trimethoprim sulfa with sperm cells.

The results of spermatozoa total motility, progressive motility, acrosomal and tail defects, acrosome reaction and damaged plasma membrane are described in Table 2. The SMT and AZI groups presented lower values ( $p<0.05)$ for TM and PM and more acrosomal and tail defects when compared with the control group. The negative correlation between motility and sperm defects described by Saacke et al. (2000) corroborate these results. The ERI group presented lower values for motility but no more acrosomal and tail defects. However, according to Stallcup \& McCartney (1953) and Back 
et al. (1975), erythromycin proved deleterious to mammalian sperm when added to semen diluents.

Table 2 - Mean \pm standard deviation of TM (total motility) (\%), PM (progressive motility) (\%), Acrosomal defects (\%), Tail defects (\%), spermatozoa with acrosome reaction (\%) and spermatozoa with damaged plasma membrane (\%) of the thawed semen samples from the experimental groups.

\begin{tabular}{lllllll}
\hline Groups & TM & PM & $\begin{array}{l}\text { Acrosomal } \\
\text { defects }\end{array}$ & $\begin{array}{l}\text { Tail } \\
\text { defects }\end{array}$ & $\begin{array}{l}\text { Acrosome } \\
\text { reaction }\end{array}$ & $\begin{array}{l}\text { Damaged } \\
\text { plasma } \\
\text { membrane }\end{array}$ \\
\hline Control & $65.7 \pm 2.08$ & $46.7 \pm 1.53$ & $3.33 \pm 0.58$ & $6 \pm 1$ & $29.8 \pm 0.1$ & $53.2 \pm 0.75$ \\
SDT & $63 \pm 1$ & $39.3 \pm 0.58$ & $2.67 \pm 0.57$ & $8 \pm 2$ & $39.4 \pm 0.55^{*}$ & $68.4 \pm 2.05^{*}$ \\
SMT & $28.3 \pm 1.53^{*}$ & $17.6 \pm 2.08^{*}$ & $11.7 \pm 3.51^{*}$ & $19 \pm 1^{*}$ & $66.1 \pm 1.15^{*}$ & $93.4 \pm 0.93^{*}$ \\
CLI & $61.7 \pm 1.53$ & $39.7 \pm 1.15$ & $6.3 \pm 0.58$ & $4 \pm 2$ & $33.2 \pm 0.05$ & $58.8 \pm 0.21$ \\
ERI & $51 \pm 1^{*}$ & $31.3 \pm 1.53^{*}$ & $4 \pm 0$ & $5.3 \pm 1.53$ & $36.3 \pm 0.15$ & $60.2 \pm 0.55$ \\
CLA & $61 \pm 2$ & $37 \pm 1$ & $1.3 \pm 1.15$ & $4.3 \pm 0.58$ & $37.5 \pm 0.55$ & $64.8 \pm 0.15$ \\
TRI & $62.3 \pm 2.08$ & $39 \pm 0$ & $3.7 \pm 1.15$ & $7 \pm 1.73$ & $36.8 \pm-0.7$ & $67.8 \pm 1.8$ \\
AZI & $29.7 \pm 0.58^{*}$ & $16.3 \pm 1.15^{*}$ & $8.3 \pm 1.15^{*}$ & $22.3 \pm 7.01^{*}$ & $47.6 \pm 1.45^{*}$ & $77.7 \pm 1.4^{*}$ \\
\hline SDT: Sulfamadiazine & with trimethoprim; SMT: Sulfamethoxazole with trimethoprim; CLI: \\
Clindamycin; ERI: Erythromycin; CLA: Clarithromycin; TRI: Trimethorpim and AZI: Azithromycin. \\
*Values presented significant difference (p<0.05) compared to the control group.
\end{tabular}

According to Maia et al. (2009) TM and PM are positively correlated with sperm viability and lower values may impair semen fertility. These parameters are closely related to the ability of the sperm cell to reach the site of fertilization (Dorado et al., 2011), thus, low motility values result in low pregnancy rates. Based on the findings of this study, Sulfamethoxazole and Trimethoprim; Erythromycin and Azithromycin should be avoided in the formulation of the semen diluent medium as they negatively affect sperm motility.

As for the flow cytometry, the SDT, SMT and AZI groups presented significantly higher ( $p$ <.05) percentages of spermatozoa with an acrosome reaction and with damaged plasma membrane compared to the control group. Probably as a consequence of osmolality and $\mathrm{pH}$ alterations, and the presence of reactive oxygen species in the dilution medium. In this case, fertilization failure could occur if semen was used in dilution medium containing these antimicrobials.

The acrosome reaction, characterized by the release of the enzymes present in the acrosome, is an important event that allows penetration of the spermatozoa in the zona pellucida and fusion with the oocyte plasma membrane at the time of fertilization (Verstegen et al., 2002). Plasma membrane plays a key role in sperm survival (Parks \& Graham, 1992) since it is responsible for the maintenance of sperm cell osmolarity. Thus, it is ideal that the plasma membrane is intact, and the acrosome preserved, as well as its enzymes (Braundmeier \& Miller, 2001; Kastelic \& Thunsathil, 2008). 
In the present study, it was observed that the SMT and AZI groups presented a reduction in sperm motility and higher percentages of spermatozoa with acrosome reaction, corroborating the results obtained by Silva et al. (2006) who observed a negative correlation between acrosome reaction and progressive sperm motility postthawing in goat semen.

The results of sperm kinetics analysis are presented in Table 3. The groups with antimicrobial did not differ in relation to the control group for ALH, STR and LIN parameters. The SDT, SMT, AZI and CLA groups showed reduction in velocities (VAP, VSL and VCL) when compared to the control group. Amirat et al. (2004) and Celeguini et al. (2008) in their studies with different diluent media for cryopreservation of semen, observed differences in sperm velocities possibly due to differences in the density of the diluents or the presence of larger particles that influence sperm velocity, which may justify the data found in the present research. Regarding BCF parameter, the CLI and AZI groups also presented lower values while the other groups were similar to the control group. According to Hoflack et al. (2007) high values of BCF and STR result in faster progressive sperm motion due to greater propulsive force. However, only the AZI group presented lower values of BCF and VSL simultaneously, whereas the CLI group showed lower BCF but with VSL similar to the control group. In this way, it is believed that clindamycin and azithromycin may be compounds which inhibit the frequency of tail beats.

Table 3 - Mean \pm standard deviation of VAP (Average Path Velocity) $(\mu \mathrm{m} / \mathrm{s})$, VSL (straight-line velocity) (m/s), VCL (curvilinear velocity) $(\mu \mathrm{m} / \mathrm{s}), \quad$ ALH (Lateral Head displacement) $(\mu \mathrm{m})$, BCF (beat/cross frequency) (Hz), STR (straightness) (\%) and LIN (linearity) (\%) of the thawed semen samples from the experimental groups.

\begin{tabular}{llllllll}
\hline Groups & VAP & VSL & VCL & ALH & BCF & STR & LIN \\
\hline Control & $49.4 \pm 0.95$ & $44.6 \pm 0.42$ & $67.6 \pm 0.35$ & $3.4 \pm 0.31$ & $16.8 \pm 0.23$ & $19 \pm 1$ & $19 \pm 2$ \\
SDT & $36.7 \pm 0.9^{*}$ & $35.3 \pm 1.05$ & $52.7 \pm 1.05^{*}$ & $3.0 \pm 0.95$ & $16.4 \pm 0.1$ & $17 \pm 0.58$ & $18 \pm 0.58$ \\
SMT & $35.4 \pm 1.75^{*}$ & $30.6 \pm 0.55^{*}$ & $52.4 \pm 0.45^{*}$ & $3.0 \pm 0.45$ & $16.4 \pm 0.25$ & $17 \pm 0.58$ & $18 \pm 2$ \\
CLI & $41.3 \pm 0.3$ & $33.6 \pm 1.4$ & $62.2 \pm 0.32$ & $2.9 \pm 0.06$ & $15.3 \pm 0.06$ & $17 \pm 0.58$ & $17 \pm 0$ \\
& & & & & & & \\
ERI & $47.5 \pm 0.5$ & $42.6 \pm 0.4$ & $64.6 \pm 0.85$ & $3.4 \pm 0.45$ & $16.3 \pm 0.3$ & $17 \pm 0.58$ & $18 \pm 0.58$ \\
CLA & $39.4 \pm 0.56$ & $36.2 \pm 0.6$ & $55.3 \pm 0.3^{*}$ & $3.2 \pm 0.2$ & $15.6 \pm 0.21$ & $18 \pm 0$ & $18 \pm 1.53$ \\
TRI & $47.1 \pm 0.8$ & $44.6 \pm 0.26$ & $61.3 \pm 0.6$ & $3.4 \pm 0.06$ & $16.8 \pm 0.1$ & $18 \pm 0.58$ & $19 \pm 1$ \\
AZI & $37.9 \pm 0.85^{*}$ & $32.6 \pm 0.5^{*}$ & $57.7 \pm 1$ & $3.2 \pm 0.12$ & $14.5 \pm 0.5^{*}$ & $17 \pm 0$ & $19 \pm 1$ \\
\hline
\end{tabular}

SDT: Sulfamadiazine with trimethoprim; SMT: Sulfamethoxazole with trimethoprim; CLI: Clindamycin; ERI: Erythromycin; CLA: Clarithromycin; TRI: Trimethorpim and AZI: Azithromycin.

*Values presented significant difference $(p<0.05)$ compared to the control group.

In this study, the antibiotics that showed the best results were clindamycin and trimethoprim alone and, therefore, can be added to the bovine semen diluent. These active principles did not differ statistically when compared to the control group in 
relation to the parameters of sperm viability. However, clarithromycin still proved to be applicable because even reducing the capacity of mitochondria in the production of ATP, the group that received this antimicrobial showed similarity in relation to motility and acrosome defects with the control group, parameters that are important in male fertility. To date, there are no studies testing the interaction of clindamycin, clarithromycin, trimethoprim alone with animal sperm cells.

\section{CONCLUSION}

Thus, under the conditions of this study, it was concluded that the antibiotics effective against $N$. caninum that were not deleterious to the spermatozoa were clindamycin, clarithromycin, and trimethoprim alone. Therefore, these active principles may be added to the diluent media for cryopreservation of semen from seropositive bulls.

\section{REFERENCES}

AMIRAT, L.; TAINTURIER, D.; JEANNEAUA, L. et al. Bull semen in vitro fertility after cryopreservation using egg yolk LDL: a comparison with Optidyl ${ }^{\circledR}$, a commercial egg yolk extender. Theriogenology, v.61, p.895-907, 2004. Available from: <https://doi.org/10.1016/S0093-691X(03)00259-0>. Accessed: May. 2017.

ANDERSON, M.L.; ANDRIANARIVO, A.G.; CONRAD, P.A. Neosporosis in cattle. Animal Reproduction Science, v.60-61, p.417-31, 2000. Available from: <https://doi.org/10.1016/S0378-4320(00)00117-2>. Accessed: Mar. 2017

BACK, D.G.; PICKETT, B.W.; VOSS, J.L. et al. Effect of antimicrobial agentes on the motility of stallion spermatozoa at various storage times, temperatures and dilution ratios. Journal Animal Science, v.41, p.137-143, 1975. Available from: <https://doi.org/10.2527/jas1975.411137x>. Accessed: Dec. 2017.

BRAUNDMEIER, A.G.; MILLER, D.J. The search is on: finding accurate molecular markers of male fertility. Journal of Dairy Science, v.84, p.1915-1925, 2001. Available from: <https://www.journalofdairyscience.org/article/S0022-0302(01)74633-4/pdf>. Accessed: Dec. 2017.

CAETANO-DA-SILVA, A.; FERRE, I.; COLLANTES-FERNÁNDEZ, E. et al. Occasional detection of Neospora caninum DNA in frozen extended semen from naturally infected bulls. 
Theriogenology, v.62, p.1329-1336, 2004. Available from: <https://doi.org/10.1016/j.theriogenology.2004.01.010>. Accessed: May. 2017.

CAMARGO, L.S.; FREITAS-DELL'AQUA, C.P.; R. SCHMITH, R. et al. New multicolor protocol to assessment dog spermatozoa by flow cytometer. Anais...VI International Symposium on Animal Biology of Reproduction, November 6-9, 2016, Campos do Jordão, SP, Brazil.

CELEGHINI, E.C.C.; ARRUDA, R.P.; ANDRADE, A.F.C. et al. Effects that bovine sperm cryopreservation using two different extenders has on sperm membranes and chromatin. Animal Reproduction Science, v.104, n.2-4, p.119-131, 2008. Available from: <https://doi.org/10.1016/j.anireprosci.2007.02.001 >. Accessed: Jan. 2018.

COLÉGIO BRASILEIRO DE REPRODUÇÃO ANIMAL (CBRA). Manual para exame andrológico e avaliação de sêmen animal, 2.ed. Belo Horizonte, 49p. 1998.

DOOSTI, A.; KHAMESIPOUR, F.; NEKOEI, S. et al. Survey for thepresence os Neospora caninum on frozen bull's sêmen samples by PCR assay. Asian Pacific Journalof Tropical Disease, v.5, n.1, p.7-12, 2015. Available from: <https://doi.org/10.1016/S22221808(14)60618-6>. Accessed: May. 2017.

DORADO, J.; ALCARÁZ, L.; DUARTE, N. et al. Changes in the structures of motile sperm subpopulations in dog spermatozoa after both cryopreservation and centrifugation on PureSperm ${ }^{\circledR}$ gradiente. Animal Reproduction Science, v.125, p.211-218, 2011. Available from: <https://doi.org/10.1016/j.anireprosci.2011.03.013>. Accessed: Dec. 2017.

DUBEY, J.P.; SCHARES. G.; ORTEGA-MORA; L.M. et al. Epidemiology and control of neosporosis and Neospora caninum. Clinical Microbiology Review, v.20, p.323-367, 2007. Available from: <doi:10.1128/CMR.00031-06>. Accessed: May. 2017.

FERRE, I.; ADURIZ, G.; DEL-POZO, I. et al. Detection of Neospora caninum in the semen and blood of naturally infected bulls. Theriogenology, v. 63, p.1504-1518, 2005.Availablefrom: <https://doi.org/10.1016/j.theriogenology.2004.07.002>. Accessed: May. 2017.

HOFLACK, G.; OPSOMER, G.; RIJSSELAERE, T. et al. Comparison of computer-assisted sperm motility analysis parameters in semen from Belgian Blue and Holstein-Friesian bulls. Reproduction Domestic Animals, v.42, p.153-161, 2007. Available from: <https://doi.org/10.1111/j.1439-0531.2006.00745.x>. Accessed: Dec. 2017. 
KASTELIC, J.P.; THUNSATHIL, J.C. Breeding soundness evaluation and semen analysis for predicting bull fertility. Reproduction in Domestic Animals, v.43, p.368-373, 2008. Available from: <https://doi.org/10.1111/j.1439-0531.2008.01186.x>. Accessed: Dez. 2017.

LINDSAY, D.S.; RIPPEY, N.S.; COLE, R.A. et al. Examination of the activities of 43 chemotherapeutic agents against Neospora caninum tachyzoites in cultured cells. American Journal Veterinary Research, v.55, n.7, p.976-981, 1994. Available from: <https://www.ncbi.nlm.nih.gov/pubmed/7978638>. Accessed: May. 2017.

LINDSAY, D.S.; BUTLER, J.M.; RIPPEY, N.S. et al. Demonstration of synergistic effects of sulfonamides and diyidrofolate reductase/thymidylate synthase inhibitors against Neospora caninum tachyzoites in cultured cells, and characterization of mutants resistant to pyrimethamine. American Journal Veterinary Research, v.57, n.1, p.68-72, 1996. Available from: <https://www.ncbi.nlm.nih.gov/pubmed/8720241>. Accessed: May. 2017.

MAIA, M.S.; BICUDO, S.D. Radicais livres, antioxidantes e função espermática em mamíferos: uma revisão. Revista Brasileira de Reprodução Animal, v.33, p.183-193, 2009. Available from: <www.cbra.org.br>. Accessed: Dec. 2017.

ORTEGA-MORA, L.M.; FERRE, I.; DEL-POZO, A. et al. Detection of Neospora caninum in semen of bulls. Veterinary Parasitology, v.117, p.301-308, 2003. Available from: <https://doi.org/10.1016/j.vetpar.2003.09.015>. Accessed: May. 2017.

PARKS, J.E.; GRAHAM, J.K. Effect of cryopreservation procedures on sperm membranes. Theriogenology, v.38, p.209-222, 1992. Available from: <https://doi.org/10.1016/0093691X(92)90231-F>. Accessed: Dez. 2017.

REICHEL, M.P.; ELLIS, J.T. If control of Neospora caninum infection is technically feasible does it make economic sense? Veterinary Parasitology, v.142, p.23-34, 2006. Available from: <https://doi.org/10.1016/j.vetpar.2006.06.027>. Accessed: May. 2017.

SAACKE, R.G.; DALTON, J.C.; NADIR, S. et al. Relationship of seminal traits and insemination time to fertilization rate and embryo quality. Animal Reproduction Science, v.60-61, p.663-677, 2000. Available from: <https://doi.org/10.1016/S0378-4320(00)001378>. Accessed: Dec. 2017. 
SERRANO, E.; FERRE, I.; OSORO, K. et al. Intrauterine Neospora caninum inoculation of heifers. Veterinary Parasitology, v.135, n.3-4, p.197-203, 2006. Available from: <https://doi.org/10.1016/j.vetpar.2005.10.003>. Accessed: Apr. 2017.

SERRANO-MARTINEZ, E.; FERRE, I.; MARTíNEZ. A. et al. Experimental neosporosis in bulls: parasite detection in sêmen and blood and specific antibody and interferon-gamma responses. Theriogenology, v.67, p.1175-1184, 2007a. Available from: <https://doi.org/10.1016/j.theriogenology.2007.01.010>. Accessed: Apr. 2017.

SERRANO-MARTINEZ, E.; FERRE, I.; OSORO, K. et al. Intrauterine Neospora caninum inoculation of heifers and cows using contaminated semen with different numbers of tachyzoites. Theriogenology, v.67, p.729-737, 2007b. Available from: <https://doi.org/10.1016/j.theriogenology.2006.10.004>. Accessed: Apr. 2017.

SILVA, A.F.; COSTA, E. P.; OLIVEIRA, F.A. et al. Uso de dimetil-formamida associada ou não ao glicerol na criopreservação de sêmen caprino. Revista Brasileira de zootecnia, v.35, n.2, p.452-456, 2006. Available at: <http://dx.doi.org/10.1590/S151635982006000200016>. Accessed: Dez. 2017.

STALLCUP, S.S.; MCCARTNEY, H.K. Toxicity to bull spermatozoa of terramycin hydrochloride and its use as an antibacterial agent in diluents. Journal dairy Science, v.36, p.293, 1953. Available from: <https://www.ncbi.nlm.nih.gov/pubmed/7454605>. Accessed: Dez. 2017.

VERSTEGEN, J.; IGUER-OUADA, M.; ONCLIN, K. Computer assisted semen analyzers in andrology research and veterinary practice. Theriogenology, v. 57, p. 149-179, 2002. Available from: <https://doi.org/10.1016/S0093-691X(01)00664-1>. Accessed: Dez. 2017. 